\title{
Acute grief experience in Diyarbakir condo- lence houses and the factors influencing the severity of grief
}

\author{
Diyarbakır'daki taziye evlerinde akut dönem yas sürecinin yaşanması ve \\ yasın ağırlık derecesine etki eden faktörlerin belirlenmesi
}

Evindar Karabulut' ${ }^{1}$ Azad Günderci², Şakir Özen ${ }^{3}$

${ }_{1}$ M.D., Private Practice, Istanbul, Turkey https://orcid.org/0000-0003-3333-0164

2M.D., Istanbul Physical Therapy and Rehabilitation Training and Research Hospital, Department of Psychiatry, Istanbul, Turkey https://orcid.org/0000-0003-4466-1794

3Prof., Private Practice, Antalya, Turkey https://orcid.org/0000-0002-6298-2551

\begin{abstract}
SUMMARY
Objective: The objectives of this study were to measure state anxiety levels of individuals in an acute grief period following the death of a close relative, and to evaluate the effects of degree of closeness and gender on grief reactions. Method: The study was conducted in condolence houses in Diyarbakir, Turkey with participants in mourning due to kinship with the deceased. One hundred twenty-two participants (49 females, 73 males) were included in the study. Fifty-four individuals (27 females, 27 males) who were not relatives of the deceased were included in the control group. After informing the participants about the study and obtaining their consent, all participants were asked to complete a survey with a sociodemographic data form, state anxiety inventory (SAI), and a list of possible behavioural reactions. Results: Acute grief experience was more severe and SAI scores were higher in first-degree relatives. When the loss was sudden, the mean SAI score was $51.8 \pm 8.9$ and when it was an anticipated death, the mean SAl score was $45.8 \pm 11.4(p<0.001)$. Grief symptoms were more severe in females compared to males $(p<0.001)$. Psychophysiological reactions of the deceased's relatives were observed to be more severe than the control group. Discussion: As the degree of closeness increases, and when the death is unexpected and sudden, individuals appear to be affected more, and have higher levels of anxiety. Females are affected by the grief process more than males.
\end{abstract}

Key Words: Acute grief, kindredship, gender, state anxiety inventory

(Turkish J Clinical Psychiatry 2021;24:135-)

DOI:10.5505/kpd.2021.65668.

\section{ÖZET}

Amaç: Bu çalışmada, bir yakını öldükten sonraki akut yas sürecindeki kişilerin durumluk kaygı düzeyleri ve diğer yas tepkilerinin belirlenmesi, yakınlık derecesinin ve cinsiyet farklılı̆ının yas tepkilerine etkisinin saptanması amaçlanmıştır. Yöntem: Çalışma Diyarbakır ve çevresindeki yerleşim merkezlerinde kurumsal hale gelmiş olan taziye evlerinde yas yaşayan ve ölenin akrabası olan 122 birey (49 kadın, 73 erkek) ile yapılmıştır. Ölenin akrabası olmayan 54 birey (27 kadın, 27 erkek) kontrol grubuna alınmıştır. Tüm katılımcılar çalışma hakkında bilgilendirilip onayları alındıktan sosyodemografik veriler, durumluk kaygı envanteri (DKE) ve yasta ortaya çıkabilecek olan duygusal-davranışsal tepkiler ile ilgili veriler kaydedilmiştir. Bulgular: Birinci derece akrabalarda akut yas diğer akrabalara göre daha şiddetli yaşanmaktadır ve DKE puanları daha yüksektir (DKE ortalaması birinci derece akrabalarda 53.3 \pm 8.9 ; ikinci derece akrabalarda 44.1 \pm 9.6 ; üçüncü derece akrabalarda $43.9 \pm 11.6$ idi; $p<0,001)$. Ani ölenlerin yakınlarında ortalama DKE puanı $51.8 \pm 8.9$ iken ölümü beklenenlerin yakınlarındaki ortalama DKE puanı $45.8 \pm 11.4$ bulundu ve ani ölümlerin yas şiddetini artırdığı saptandı $(p<0.001)$. Kadınlarda yas semptomlarının daha şiddetli olduğu belirlendi. Kadınlarda DKE puanı 53.7 \pm 8.2 ; erkeklerde $45.4 \pm 10.8$ bulundu $(p<0.001)$. Kontrol gurubu ile kıyaslandığında akrabalardaki psikofizyolojik tepkilerinin daha yoğun olduğu saptandı $(p<0.001)$. Sonuç: Yas kültürden kültüre ve bireyden birey çeşitlilik gösteren bir süreçtir. Yakınlık derecesi artıkça ve ölüm beklenmedik ve ani olunca yaslı kişiler daha çok etkilenmekte, kaygı düzeyleri daha yüksek çıkmaktadır. Kadınlar yas sürecinde erkeklerden daha çok etkilenmektedir.

Anahtar Sözcükler: Akut yas, akrabalık, cinsiyet, durumluk kaygı envanteri 


\section{INTRODUCTION}

Death is the inevitable truth of all living creatures. The end of the deceased's life marks the beginning of the grief process for those who remain behind. Although ceremonies and rituals vary across cultures and religions, grief and condolence are fairly ubiquitous concepts. After birth, we build relationships with significant others throughout our lives. These relationships continue to evolve and, from time to time, are disrupted. When a close one dies, the meaning of life is altered. Adding meaning to this change through the grief process could provide a growth motivation for the bereaved (1). Grief is a process over which the psyche heals itself following a feeling of loss. Grief is personal, and is unique to everyone, just like a fingerprint (2).

\section{Grief Reaction}

Grieving, which could simply be defined as the psychological reaction against any loss and change, is the set of reconciliations we make in order to harmonise our inner world with reality. Death is the most tangible of all losses. Death and the following grief is a personal event taking place in a specific environment. Societies and religions have developed series of rules and norms for this event $(1,3)$. The word grief, in its contemporary use, refers to a series of culturally, socially and religiously defined procedures and practices.

Bowlby's attachment theory helps us comprehend the human need for forming strong affective bonds, as well as the affective reactions that occur when these bonds are threatened or broken. According to Bowlby, attachment stems from a need for security, develops early in life, is often directed towards a number of significant individuals, and tends to endure for the large part of the life cycle. Forming bonds with significant others is considered a normal behaviour not just for the child, but also for the adults. When the attachment figure disappears from sight or when their existence is threatened, the reaction is an intense anxiety and a strong emotional protest (4).

Larger the potential loss, the more intense and versatile the reactions are. The loss is usually followed by withdrawal, apathy, and frustration. Bowlby has defined three phases of response for loss (4). These phases are 1) the phase consisting of apathy, disbelief, pain and at times bursts of anger; 2) yearning, and an effort to recontact with the lost object or the mementos, which is usually accompanied by anxiety; 3) disorganisation, despair and apathy expressed as depression, and the self-destruction of the individual's previous existence. Bowlby later includes a healing phase to these original three.

Many authors have defined the grief process by dividing it up to various stages (5-7). Worden, on the other hand, has first defined the signs of grief, and then classified them into categories such as feelings, thoughts, bodily symptoms, and behaviours (8). Similarly, Erich Lindemann has studied the grief reactions of individuals who lost their loved ones in a fire in Boston, and explained these reactions systematically (9). Elisabeth Kübler-Ross has worked with terminal cancer patients, and has divided their post-diagnosis life into five stages - denial and isolation, anger, bargaining, depression, and acceptance (10).

As a result, grief is a process and many individuals complete this process through social and religious rituals. However, grief process may never be completed or may lead to disorders such as depression or anxiety in some individuals, depending on factors such as unexpected and sudden death, stigmatised deaths (AIDS, etc.), personality structure of the individual, low self-esteem, high dependency, ambivalent feelings, insecure attachment styles, form of loss, and previous psychiatric history $(3,6$, $8,11,12)$. Viewed from another perspective, when processed properly, grief may not only signify parting ways with the deceased, but may also act as a compass for beginning new relationships and adding meaning to one's life.

Complicated grief consists of confusing terminology referring to grief, such as abnormal, atypical, distorted, morbid, traumatic, and unresolved. One of the first authors attempting to discuss and explain this topic was Freud, who has defined depression (or, in his own words, "melancholy") as a pathological form grief, and has suggested the anger towards the lost object turning towards one's self as 
the cause behind it (5).

Depression is a psychiatric disorder which disrupts the individual's social adaptation and functionality. It is defined by certain symptoms in Diagnostic and Statistical Manual of Mental Disorders IV (DSMIV) (13). The person in depression evaluates oneself as weak, lacking, and bad. Unlike grief, depression can begin any time, and does not require a loss to take place. DSM-IV tries to differentiate grief from depression by criteria such as a 2-week duration limit, preservation of self-esteem, and lack of suicidal thoughts. However, the difference between depression and bereavement remains a hot topic (14).

\section{Death and condolence in Islamic culture}

Primary resources such as the Quran and hadiths discuss the topics of life, life's purpose, death, and afterlife extensively. According to the Islamic belief, immortality is reserved for Allah, and therefore all living creatures are destined to experience death. Condolence is solely about providing comforting and consoling words to the bereaved, and showing sympathy. Most common phrases used in expressing condolence are "May Allah bestow upon you good patience, and its reward", "May you stay alive", and "May Allah grant those remain more time to live" (15). The period of condolence is three days for people who live in the same city. It is mustahabb (a behaviour that counts as a good deed even though it is not religiously ordered) to express condolences within three days. Condolences after three days are considered makruh for preventing the bereaved's to return to normal life. Close relatives of the deceased can remain in their houses or a more appropriate place for three days to receive condolences. Although expressing condolences after three days is acceptable for those who live in other locations or are unaware of the news, the recommended practice is completing the condolence process in three days (15).

\section{Condolence Houses in Diyarbakir}

Expressing and accepting condolence is one of the most prominent traditions of Muslim cultures.
Condolences are usually expressed and accepted in the deceased's house, but locations such neighbours' houses, backyards, tents or meeting halls are also commonly preferred if they are easy to access to and provide advantages for hosting the visitors for short periods of time. With the expansion of cities, the changes in house styles and family systems, the increase in communication, and reasons as such, condolence as a social need began to require larger spaces. The "condolence house", which is an institutional site, has first appeared in the early 1990s in Diyarbakir and its neighbouring cities, and has, over the past 20 years, become widespread. Condolence houses are usually located near the streets in the city centre or inside the mosque courtyards, are easy to find and access to, and have enough seats for the visitors and a kitchen for serving tea or coffee. Some also include a manager's office and a prayer room. These houses are usually established through the financial support of benefactors, but they may be also established by city/town or mosque associations. No fee is charged for using the condolence house, but the bereaved is expected to contribute to expenses such as electricity, water, tea, sugar, etc., if their finances allow it. Condolences are usually accepted for three days in these houses. Although the official number is not available, based on our observations, it is safe to say that there are over 30 condolence houses in Diyarbakir.

In this study, we investigated the reactions against death, severity of the loss' effect, state anxiety levels, some other affective-behavioral responses in grief and the way these responses are expressed among the bereaved.

\section{METHODS}

After receiving approval from Ethics Committee of Dicle University, Faculty of Medicine (Date and Issue No: 18/05/2010 - 12-2h.05.10), the study was conducted in randomly selected 15 condolence houses located in Diyarbakir, Turkey, between May and July, 2010.

\section{Study Population}

We have visited the condolence ceremony of 53 
individuals deceased in different days, offered our sympathies to the bereaved, introduced ourselves, informed them about our study, and obtained the consent of those fitting participation criteria, which included a minimum of 18 years of age, showing mental capacity to understand the questionnaires, and be related to the deceased. At each ceremony visited, 1 to 5 relatives were included in the study. For the study group, we have met with 229 people, informed them about the study, and asked them to fill the questionnaire. Among these, 72 relatives refused to participate due to various reasons and 35 participants were excluded from the analysis because of wrongly completed or incomplete questionnaires. As a result, a total of 122 participants were included in the final analysis as a part of the study group.

The control group was made up of individuals who were present in the condolence house for showing their sympathies, but did not have any kinship with the deceased. These participants were also older than 18 , and had similar sociodemographic characteristics with the study group. After the individuals were informed about the study, those agreeing to participate were provided the same questionnaires. At each condolence ceremony, similar to the study group, 1 or 2 participants were recruited to the control group. We have met with a total number of 75 people to include in the control group, 21 of which were excluded due to wrongly completed or incomplete questionnaires. In the end, the control group consisted of 54 individuals.

\section{Questionnaire}

All participants recruited to the study were asked to answer the questions in a previously prepared questionnaire form which consisted of 3 sections. In the first section, there were questions regarding the sociodemographic information of the deceased and the participant, relationship with the deceased, religious beliefs, etc. In the second section, there was a list of frequently observed symptoms during grief, which were to be evaluated on a 5-point Likert-type scale. The third section was the State Anxiety Inventor (SAI, STAI-I). Questions about the deceased and the relationship with the deceased were excluded from the questionnaire presented to the control group, however the remaining sections were the same for both groups. In cases where the participant did not have a clear understanding of Turkish language, the questions were read to the participant in Kurdish and given answers were recorded on the questionnaire.

State Anxiety Inventory (SAI) consists of 10 direct and 10 reverse items investigating anxiety symptoms (16). The direct items are scored as not at all $=1$, somewhat $=2$, moderately so $=3$, very much so $=4$. The reverse items, on the other hand, are scored as not at all $=4$, somewhat $=3$, moderately $\mathrm{so}=2$, very much so $=1$. Cut-off point was predetermined to be 40 , scores of 41 and above were evaluated as anxious, and those of 40 and below were rated as normal.

Degree of closeness were divided into 3 categories: mother, father, child, sibling, and spouse were considered first-degree relatives; grandmother, grandfather, nephew, uncle and aunt were classified as second-degree relatives; and finally, bride, aunt-inlaw, co-sister-in-law, and others were accepted to be third-degree relatives.

\section{Statistical analyses}

Comparison of parametric variables were with the t-test for two groups, and with analysis of variance for three groups. For nonparametric comparisons of two groups (e.g. grief symptoms) Mann Whitney $\mathrm{U}$ test was utilised. Relationship between SAI scores and grief symptoms was analysed using Spearman's correlation test. Categorical variables were compared with chi square test. Data analyses were conducted in SPSS (Statistical Package for Social Sciences, SPSS Inc. SPSS Statistics for Windows, Version 11.5, Chicago, USA). A p value lower than 0.05 were accepted to be significant.

\section{RESULTS}

Of the 53 deceased, 26 were female and 27 were male. Majority were over 50 years old, $36(67.9 \%)$ were married, $17(32.1 \%)$ were single or widowed. As for the deceased's level of education, the highest percentage was for primary school graduates 
Table 1. Sociodemographic characteristics of the two groups.

\begin{tabular}{|c|c|c|c|c|}
\hline $\begin{array}{l}\text { Sociodemographic characteristics } \\
\text { Gender }\end{array}$ & \multicolumn{2}{|c|}{$\begin{array}{l}\text { Study Group (n:122) } \\
\text { Number }(\%)\end{array}$} & \multicolumn{2}{|c|}{$\begin{array}{l}\text { Control Group (n:54) } \\
\text { Number }(\%)\end{array}$} \\
\hline Female & 49 & $(40.2)$ & 27 & $(50.0)$ \\
\hline Male & 73 & $(59.8)$ & 27 & $(50.0)$ \\
\hline \multicolumn{5}{|l|}{ Age } \\
\hline $18-30$ & 38 & (31.1) & 22 & $(40.7)$ \\
\hline $31-40$ & 35 & $(28.7)$ & 22 & $(40.7)$ \\
\hline $41-50$ & 31 & $(25.4)$ & 8 & (14.8) \\
\hline 51 and above & 18 & $(14.8)$ & 2 & $(3.7)$ \\
\hline \multicolumn{5}{|l|}{ Occupation } \\
\hline Farmer, retired, artisan, worker & 20 & $(16.4)$ & 3 & $(5.6)$ \\
\hline Housewife & 25 & $(20.5)$ & 7 & $(13.0)$ \\
\hline Self-employed & 31 & $(25.4)$ & 7 & $(13.0)$ \\
\hline Student & 10 & $(8.2)$ & 4 & $(7.4)$ \\
\hline Unemployed & 9 & $(7.4)$ & 2 & $(3.7)$ \\
\hline Government officer & 27 & $(22.1)$ & 31 & $(57.4)$ \\
\hline \multicolumn{5}{|l|}{ Education level } \\
\hline Illiterate & 1 & $(0.8)$ & 2 & $(3.7)$ \\
\hline Primary school & 35 & $(28.7)$ & 9 & $(16.7)$ \\
\hline Middle school & 13 & $(10.7)$ & 5 & $(9.3)$ \\
\hline High school & 32 & $(26.2)$ & 4 & $(7.4)$ \\
\hline University & 41 & (33.6) & 34 & $(63.0)$ \\
\hline \multicolumn{5}{|l|}{ Marital status } \\
\hline Married & 83 & $(68.0)$ & 30 & $(55.6)$ \\
\hline Single & 39 & $(32.0)$ & 24 & $(44.4)$ \\
\hline
\end{tabular}

$(60.4 \%)$, followed by illiterates $(15.1 \%)$. Economic status of the deceased person was evaluated by their loved ones and results indicated that $58.5 \%$ had middle income level, $20.8 \%$ had high income level, and $20.8 \%$ had low income level. Cause of death was illness for $39(73,6 \%)$, old age for 7 $(13.2 \%)$, traffic accident for $4(7.5 \%)$, and suicide for $3(5.7 \%)$.

Sociodemographic characteristics of participants who successfully completed our questionnaires and were included in either the study group or the control group are presented in Table 1 . Their degree of kinship with the deceased is summarised in Table 2. Degree of kinship was evaluated in terms of its effect on acute anxiety. The mean score for SAI was $53.3 \pm 8.9$ for the first-degree relatives, 44,1 $\pm 9,6$ for the second-degree relatives, and 43,9 $\pm 11,6$ for the third-degree relatives. Acute anxiety level of the first-degree relatives was higher than the second- and third-degree relatives $(\mathrm{p}<0,001)$. Relationship between SAI scores (anxious/not anxious) and degree of kinship is presented in Table 3.

The mean SAI score in the study group was 45.4 \pm 10.8 for males, and $53.7 \pm 8.2$ for females $(p=0.000)$. As for the control group, mean SAI scores for males and females were $40.9 \pm 9.9$ and $44.7 \pm 11.4$, respectively $(\mathrm{p}=0.192)$.

A total of 27 males (22.1\%) and 10 females (\%8.2) in the study group, as well as 16 males (29.6\%) and 
Karabulut E, Gunderci A, Ozen S.

Table 2. Gender distribution based on the degree of kinship.

\begin{tabular}{|c|c|c|c|c|c|c|c|c|}
\hline \multirow{2}{*}{$\begin{array}{l}\text { Gender } \\
\text { Female }\end{array}$} & \multicolumn{2}{|c|}{$\begin{array}{l}\text { First-degree } \\
\text { Relative } \\
\mathrm{N}(\%)\end{array}$} & \multicolumn{2}{|c|}{$\begin{array}{l}\text { Second-degree } \\
\text { Relative } \\
\mathrm{N}(\%)\end{array}$} & \multicolumn{2}{|c|}{$\begin{array}{l}\text { Third-degree } \\
\text { Relative } \\
\text { N }(\%)\end{array}$} & \multicolumn{2}{|c|}{$\begin{array}{l}\text { Total } \\
\text { N (\%) }\end{array}$} \\
\hline & 28 & $(23.0)$ & 11 & (9.0) & 10 & (8.2) & 49 & $(40.2)$ \\
\hline Male & 34 & (27.9) & 26 & $(21.3)$ & 13 & (10.7) & 73 & (59.8) \\
\hline
\end{tabular}

7 females $(13.0 \%)$ in the control group reported to death $(n=83 ; 47.2 \%)$. Other answers were death of be smokers. Use of other substances or alcohol were not detected in either group.

When asked about the reason for choosing this particular condolence house, the answer was easy access for $64(52.5 \%)$; hometown ties, previous visits or knowing the manager for $53(43.4 \%)$; and the will of the deceased for $5(4.1 \%)$ of the participants.

In this study, 118 individuals from the study group reported belief in afterlife, and 4 indicated a disbelief on the matter. In the control group, 50 participants stated that they believed in life after death, while 4 replied they did not. Since there is a large difference between group sizes, possible effects of belief and religious practices on grief symptoms and anxiety levels were not examined in detail.

Sixteen $(13.1 \%)$ participants in the study group reported a history of previous physical illness, which were prevalent diseases such as diabetes mellitus, hypertension, chronic obstructive lung disease, and cardiac problems. Two individuals in the study group reported a psychiatric disorder (depression and anxiety disorder). There were not any reports of disease history in the control group.

Participants in both groups were asked "Which deaths cause the most pain to the deceased?" The young people $(n=20 ; 11.4 \%)$, murder $(n=3 ; 1.7 \%)$, suicide $(2.8 \%)$, death by suffering $(n=8 ; 4.5 \%)$, traffic or occupational accidents $(n=7 ; 4.0 \%)$, and death of a family member $(n=14 ; 8.0 \%)$. In total, 36 participants left this question blank.

Sudden deaths were found to cause more acute anxiety in the study group. The mean SAI score of the bereaved who had lost their loved one's to a sudden death was $51.8 \pm 8.9$. When the death was anticipated, the mean SAI score was 45.8 \pm 11.4 . The difference between the two groups was significant $(\mathrm{p}=0.001)$.

Among the physical changes reported in the grief process, two most common were irregularities in the blood pressure $(30.3 \%)$ and weakened immune system (27\%). All the reported physical changes were significantly more common in the study group Table 4.

Correlation between some of the affective reactions of the participants in the acute grief period and their SAI scores were calculated, and a positive $(r>0)$ correlation was determined in the study group for all affective reactions except joy. The positive correlation was even more significant for especially the feeling of emptiness and not being supported, problems of diet and appetite, sadness and crying Table 5. most frequent reply was sudden and unexpected

Table 3. Anxiety levels among the bereaved relatives based on the State Anxiety Inventory (SAI) score

\begin{tabular}{|c|c|c|c|c|c|c|c|}
\hline \multirow{2}{*}{$\begin{array}{l}\text { State of anxiety } \\
\text { Anxious } \\
\text { (SAI score ?41) }\end{array}$} & \multicolumn{2}{|c|}{$\begin{array}{l}\text { First-degree } \\
\text { Relative } \\
\mathrm{N}(\%)\end{array}$} & \multicolumn{2}{|c|}{$\begin{array}{l}\text { Second-degree } \\
\text { Relative } \\
\mathrm{N}(\%)\end{array}$} & \multicolumn{2}{|c|}{$\begin{array}{l}\text { Third-degree } \\
\text { Relative } \\
\mathrm{N}(\%)\end{array}$} & \multirow{2}{*}{$\begin{array}{l}\mathrm{P} \text { value } \\
<0.001\end{array}$} \\
\hline & 58 & $(47.5)$ & 24 & (19.7) & 16 & $(13.1)$ & \\
\hline $\begin{array}{l}\text { Normal (not anxious) (SAI } \\
\text { score }<40 \text { ) }\end{array}$ & 4 & (3.3) & 13 & (10.7) & 7 & (5.7) & $>0.05$ \\
\hline Total & 62 & $(50.8)$ & 37 & $(30.3)$ & 23 & (18.9) & - \\
\hline
\end{tabular}


Table 4. Psychopathological and physiopathological changes observed due to sadness during condolence days

\begin{tabular}{|c|c|c|c|c|c|}
\hline \multirow{2}{*}{$\begin{array}{l}\text { Psychopathological and Physiopathological } \\
\text { Changes } \\
\text { Irregular blood pressure }\end{array}$} & \multicolumn{2}{|c|}{$\begin{array}{l}\text { Study Group } \\
\mathrm{N}(\%)\end{array}$} & \multicolumn{2}{|c|}{$\begin{array}{l}\text { Control } \\
\text { Group } \\
\mathrm{N}(\%)\end{array}$} & \multirow{2}{*}{$\begin{array}{l}\text { P value } \\
<0.001\end{array}$} \\
\hline & 37 & $(30.3)$ & 5 & $(9.2)$ & \\
\hline $\begin{array}{l}\text { Weakened immune system (symptoms such as } \\
\text { inflammations, acne, herpes, etc.) }\end{array}$ & 33 & $(27.0)$ & 5 & $(9.2)$ & $<0.001$ \\
\hline Irregular blood sugar levels & 25 & $(20.4)$ & 2 & (3.7) & 0.003 \\
\hline Picking fights and harming one s environment & 11 & $(9.0)$ & 0 & $(0)$ & - \\
\hline Feeling unwell enough to call an ambulance & 6 & (4.9) & 1 & $(1.8)$ & 0.017 \\
\hline Suicide attempt or suicidal ideas & 4 & $(3.2)$ & 0 & $(0)$ & - \\
\hline
\end{tabular}

Some of the psychological symptoms reported by the study group were more severe than those of the control group. Although the difference between the two groups were significant in almost all evaluated symptoms, this was more evident especially for having intense thoughts and daydreams about the deceased, sadness and crying, sleep problems, and dietary and appetite problems Table 6 .

\section{DISCUSSION}

Regardless of culture or geography, losing a loved one causes sadness. In the various indexes we have searched, we have not come across any studies focusing on the first days of grief. In this study, we aimed to understand the grief atmosphere during the first 3 days, by including a control group. However, since the data collection took place at a time when individuals were highly distressed, there were understandably people who refused to parti-

Table 5. Correlation between the SAI scores and psychological symptoms

\begin{tabular}{|c|c|c|}
\hline Psychological Symptoms & $\begin{array}{l}\text { Study Group } \\
\mathrm{r} \text { Value and Level of } \\
\text { Significance }\end{array}$ & $\begin{array}{l}\text { Control Group } \\
\mathrm{r} \text { Value and Level of } \\
\text { Significance }\end{array}$ \\
\hline Perceiving death as a dream, rather than the reality & $0.456^{* * *}$ & 0.221 \\
\hline Intense thoughts and daydreams about the deceased & $0.531^{\cdots *}$ & 0.0914 \\
\hline Sadness, crying & $0.584^{\cdots}$ & 0.009 \\
\hline Joy & $-0.186^{*}$ & $-0.055 i$ \\
\hline Guilt & $0.363^{\cdots}$ & $0.136 t$ \\
\hline Anger & $0.379^{* *}$ & $0.113 i$ \\
\hline Excitability & $0.431^{\cdots *}$ & $0.036 t$ \\
\hline Bewilderment, numbness & $0.543^{\cdots}$ & 0.3094 \\
\hline Seeing life as empty and meaningless & $0.426^{* * *}$ & $0.442 i$ \\
\hline Feeling empty and unsupported & $0.594^{* *}$ & $0.463 i$ \\
\hline Thinking about future problems & $0.271^{* *}$ & 0.327 \\
\hline Presuming to see the image of the deceased & $0.397^{* * *}$ & 0.232 \\
\hline Presuming to hear the voice of the deceased & $0.495^{* *}$ & $0.235 i$ \\
\hline Fainting due to sadness or distress & $0.459^{* * *}$ & $0.063 i$ \\
\hline Physical expressions of lamenting, such as tearing one's clothes & $0.415^{* *}$ & 0.131 \\
\hline Sleep problems & $0.561^{\cdots *}$ & 0.2724 \\
\hline Dietary and appetite problems & $0.587^{* *}$ & $0.334 t$ \\
\hline
\end{tabular}

**P< $<0.001, * * \mathrm{P}<0.01,{ }^{*} \mathrm{P}<0.05,+\mathrm{p}=$ not significant, $\mathrm{r}=$ correlation coefficient 
Karabulut E, Gunderci A, Ozen S.

\begin{tabular}{llll}
\hline \multicolumn{3}{l}{ Table 6. Severity degrees of some of the psychological symptoms that can occur during acute grief process in study and } \\
control groups & $\begin{array}{l}\text { Study Group } \\
\text { Mean SD }\end{array}$ & $\begin{array}{l}\text { Control Group } \\
\text { Mean } \pm \text { SD }\end{array}$ & P value \\
\hline Psychological Symptoms & $2.7 \pm 1.6$ & $2.1 \pm 1.2$ & 0.004 \\
\hline Perceiving death as a dream, rather than the reality & $3.5 \pm 1.2$ & $2.4 \pm 1.2$ & 0.000 \\
Intense thoughts and daydreams about the deceased & $3.7 \pm 1.1$ & $2.7 \pm 1.2$ & 0.000 \\
Sadness, crying & $1.2 \pm 0.2$ & $1.1 \pm 0.7$ & 0.004 \\
Joy & $1.7 \pm 1.2$ & $1.3 \pm 0.7$ & 0.006 \\
Guilt & $1.7 \pm 1.0$ & $1.5 \pm 0.6$ & $0.187 \ddagger$ \\
Anger & $2.5 \pm 1.3$ & $2.1 \pm 1.1$ & 0.009 \\
Excitability & $2.8 \pm 1.3$ & $2.4 \pm 1.3$ & 0.021 \\
Bewilderment, numbness & $2.8 \pm 1.6$ & $2.7 \pm 1.6$ & $0.244 !$ \\
Seeing life as empty and meaningless & $2.5 \pm 1.5$ & $2.2 \pm 1.4$ & 0.050 \\
Feeling empty and unsupported & $2.6 \pm 1.3$ & $2.7 \pm 1.4$ & $0.745 \dagger$ \\
Thinking about future problems & $2.7 \pm 1.5$ & $1.8 \pm 1$ & 0.000 \\
Presuming to see the image of the deceased & $2.3 \pm 1.5$ & $1.4 \pm 0.9$ & 0.000 \\
Presuming to hear the voice of the deceased & $1.5 \pm 1.0$ & $1.1 \pm 0.1$ & 0.002 \\
Fainting due to sadness or distress & $1.2 \pm 0.7$ & $1.1 \pm 0.5$ & 0.017 \\
Physical expressions of lamenting, such as tearing one's clothes & $2.5 \pm 1.5$ & $1.5 \pm 1.0$ & 0.000 \\
Sleep problems & $2.4 \pm 1.4$ & $1.7 \pm 1.1$ & 0.000 \\
\hline Dietary and appetite problems & & \\
\hline
\end{tabular}

i $\mathrm{p}=$ not significant, $\mathrm{M}=\mathrm{Mean}, \mathrm{SD}=\mathrm{Standard}$ Deviation cipate.

Diyarbakir's condolence houses provided us an opportunity to reach out to the bereaved during the first days after their loss. Previous studies have sent out letters or conducted face-to-face interviews few weeks later, asking their participants to reflect back on their emotions during the time period following the loss. In our study, data were directly collected from the bereaved individuals within the first days of grief.

Acute anxiety symptoms were higher for participants who had lost their loved ones to a sudden death $(3,17-19)$. In this study, even though majority of the deceased were older than 50 and more than half of the deaths were reported to be anticipated, SAI scores were found to be higher in the firstdegree relatives, similar to the results of previous studies. Our participants have reported sudden death as the most painful form of death for those who are left behind, followed by suicide and murder.

The high number of male participants in the study group is due to the fact that Diyarbakir's condolence houses serve mostly to males and that the male population was easier to contact for the researchers. Sociodemographic characteristics of study and control groups were considered similar.

There are a limited number of studies conducted within the first days of grief. Most studies take place weeks or months after the loss. Our study, on the other hand, investigates the psychological excitations and reactions in the first few days. As expected, higher degrees of grief symptoms and anxiety levels were observed in close relatives of the diseased, compared to those who did not have any kinship with them.

A relationship between the severity of grief and degree of kinship with the deceased was also previously reported $(1,7,17,20-22)$. In parallel to the results of these studies, first-degree relatives in our study had higher SAI scores, and their affective and behavioural symptoms were more intense. 
As many studies indicate, basal anxiety level is higher in females, and they respond to distressing events in a more emotional and behavioural manner $(23,24)$. Similarly, we have observed the highest degree of anxiety in the female relatives of the deceased, followed by their male relatives, females who were not related to them, and lastly males who were not related to them. Literacy and financial independence rates in Diyarbakir are low among females, which may give occasion to preoccupation with uncertainties and hardships following the loss, and therefore increasing the anxiety level. We have not come across any studies focusing on this issue by comparing relatives with non-relatives, which may be a topic of interest for future research.

Studies conducted in various countries have reported on the effects of belief in afterlife and adhering to the practices of their religion on the intensity of grief (25). In our study, however, there were not enough individuals reporting a disbelief in the afterlife, making it impossible to comment on the effects of belief on the grief process.

Distressing events have been suggested to cause more or less psychological and physiological changes in individuals $(21,26)$. Our results, too, support such previous findings. For example, in the study group, complaints such as irregularities in blood sugar, blood pressure and immune system as well as frantic anger reactions were reported.

A significant positive correlation was observed between acute anxiety level in the study group and the severity degree of some of the emotional and behavioural symptoms that may appear in the grief process. The most common complaints in the study group were intense thoughts and daydreams about the deceased, sadness and crying, sleep problems, and dietary and appetite problems.

Condolence houses in Diyarbakir could be argued to be beneficial places for enabling psychosocial support and complementing the grief process. Recently, England has also detected the value of grief-support, undertaking various arrangements on the matter. However, the support provided by the professionals is reported to be different from the support provided by groups working on a volun- tary basis (27).

In conclusion, there is, to our knowledge, no other studies focusing on the grief reactions during the first 3 days after the loss, measuring state (acute) anxiety, and using a control group for comparison, making our study among the first on this area. As a result of this study, we have observed that (a) firstdegree relatives of the deceased are more affected during the acute grief period, (b) females experience this process more intensely, and (c) sudden deaths are more traumatic for the bereaved. Our results also indicate that support is of utmost importance for the bereaved to reorganise their lives and experience the process after loss as less traumatic. The positive role Diyarbakir condolence houses play during the acute grief process requires further investigation. Studies including individuals who go through the grief process in their own houses due to various reasons and comparing their thoughts and emotions could provide more explanatory results.

\section{Conflicts of Interest}

The authors have no conflict of interest to declare.

\section{Acknowledgements}

No funding was received for this study. The authors would like to thank the study participants who took part in this research and B. Murat Ozdemir for his editorial support in writing this manuscript.

Correspondence address: M.D., Azad Gunderci, Istanbul Physical Therapy and Rehabilitation Training and Research Hospital, Department of Psychiatry, Istanbul, Turkey drazadgunderci@yahoo.com 


\section{REFERENCES}

1. Malkinson R. Cognitive-Behavioral Therapy of Grief: A Review and Application. Research on Social Work Practice 2001;11:671-698

2. Goka E. Psychology of death, dying, and those remain behind. Timas Publications 2009

3. Jacob S. Traumatic Grief Brunner/Mazel group New York 1999

4. Bretherton I. The origins of attachment theory: John Bowlby and Mary Ainsworth reference: developmental psychology 1992;28: 759-775.

5. Freud S. Mourning and Melancholia. Standard edition, (vol.XIV) 1917

6. Parkers CM. Breavement: studies of grief in adult life third edition Penguin Books New York 1998

7. Volkan V. Life After Loss: The Lessens of Grief. (I. Vahip \& M. Kocadere, Trans.) Halime Odag Foundation Publications, İzmir. 1999; 17-49.

8. Worden JW. Grief counseling and grief therapy: A handbook for mental health workers (B. Oncu, Trans.), Ankara University School of Medicine Publications, Ankara 2003

9. Lindemann E. Symptomology and management of acute grief, American Journal of Psychiatry 1944;101,141-148.

10. Kübler-Ross E. On Death and Dying. Boyner Publications (B. Buyukkal, Trans.) İstanbul 1997

11. Zisook S, Shear K. Grief and bereavement: what psychiatrists need to know. World Psychiatry 2009;8:67-74.

12. Shear K, Shair H. Attachment, Loss and Complicated Grief DEV psycohobial, 2005

13. American Psychiatric Association. Diagnostic and Statistical Manual of Mental Disorders, 4th Edition (DSM-IV) (E. Koroglu, Trans.) Doctors Publishing Association, Ankara 1995.

14. Zisook S, Zisook SA. Death, dying, and bereavement. Comprehensive Textbook Of Psychiatry, 8 edition:, B Sadock $(\mathrm{H}$ Aydin, Trans.) Gunes Publishing House, Ankara, 2007.

15. Apaydin YH. Salah, catechism, and religious practices, 14th ed., Ankara, TDV Publishing, Volume I, 2007;354-370.

16. Oner N, LeCompte A. Discontionary and contionary anxiety inventory book (2nd ed.), Bogazici University Publishing Center, Istanbul, Turkey 1998

17. Feigelman W, Jordan JR, Gorman BS. How they died, time since loss, and bereavement outcomes William feigelman, ph.d. nassau community college, garden city, new york omega 2009;58:251-273

18. Kent H. Sudden Bereavement in Acute Care Setting, October 2004 20A/ol19/no6/

19. Fujisawa D. Journal of Affective Disorders JAD-04627; 2010:p7

20. Laurie A, Neimeyer RA. African Americans in Bereavement: Grief as a Function of Ethnicity Omega 2008;57:173-193.

21. Boelen PA, Marcel A. The factor structure of Posttraumatic
Stress Disorder symptoms among bereaved individuals: A confirmatory factor analysis stud, Journal of Anxiety Disorders 22, 2008

22. Ozcetin A. Relationship between bereavement and religion in Diyarbakir region. Dusunen Adam: The Journal of Psychiatry and Neurological Sciences 2000;13(1).

23. Merikangas KR. Death, dying, and bereavement. Comprehensive Textbook Of Psychiatry 8 edition: Benjamin Sadock (H. Aydin, Trans.) Gunes Publishing House Ankara 2007

24. Najip A, Lorberbaum J.P, Kose S, et al. Regional Brain Akctivity in Women Grieiving a Romantic Relationship Breakup, Am J Psychiatry 2004;161:2245-2256.

25. Becker G, Xander CJ, Blum HE, et al. Do religious or spiritual beliefs influence bereavement? A systematic review. Palliative Medicine 2007;21:207-217

26. Germain A, Shear K, Monk TH et al. Behavioral Sleep Medicine 2006;4:152-163.

27. Field D, Payne S, Relf M. Some issues in the provision of adult bereavement support by UK hospices. Social Science \& Medicine 2007;64:428-438. 